\title{
航海環境時系列画像からのリアルタイム船舶抽出手法
}

\author{
周立輝 ${ }^{*}$ 新保雅俊** 大島正毅***
}

\section{Method for Real-Time Detecting Ships using Navigational Image Sequence}

\section{Riki SHU, Masatoshi SHIMPO and Masaki OSHIMA}

\begin{abstract}
This paper proposes a method for detecting ships on real-time using navigational image sequence. As pointed out in the previous reports, our proposed method has problem in processing speed performance, although it is precise precision.

First, this paper analyzes this problem, and proposes a new method for solving them.

Our method distinguishes ships from the character of a moving vector of region. A moving vector is calculated on matching process of region. Matching process takes enormous-processing time.

On the other hand, the Lucas-Kanade method (LKM) is popular version two-frame differential methods for optical flow estimation. The LKM can get a pixel flow first. We examined that applying the LKM in substitution for matching process, and we proposes a new method for detecting ships on real-time. We inspected an effect of prposed method by an experiment.
\end{abstract}

Keywords: Image processing, Information system, Real-Time, Image sequence, Navigation system キーワード：画像処理，情報処理，リアルタイム，時系列画像，航行システム

\section{1.はじめに}

海上保安庁の統計によると海難に遭遇する船舶 隻数は過去 5 年間で減少傾向にあったが、平成 18 年の海難船舶隻数は 2544 隻となり平成 17 年に比べ て 62 隻增加した。海難原因の 7 割は人為的要因で あると分析されており、その中でも見張りの不十分 を原因とする衝突事故が最も多い(1)。

筆者らは画像処理の技術を用いて安全な航行を 支援する「航海情報システム」の構築(2)に取組んでい る。これは海上の見張りやレーダ、AIS 等の航海機 器の監視を画像処理技術で支援するシステムである。 具体的には海上の見張りにおいてはカメラで撮影し た画像から他の航行船舶を抽出することで見張りの 支援を行う。レーダの監視においては小型船舶等の
近距離では確認し難い船影の抽出を支援する。 ARPA は比較的遠方の大型船舶の動向把握に有効で あるが、近接する小型船舶等の抽出が可能になるこ とで衝突の防止により効果がある。レーダ、AIS、 ECDIS 等の既存の航海機器類と、画像処理で得た 情報を統合することで、それぞれの情報が持つ欠点 を補完することが出来、より信頼性の高い「航海情 報システム」の実現が可能となる。

本論は海上の見張り支援に注目し、カメラで撮影 した画像から船舶をリアルタイムに抽出する手法を 提案する。すでに画像から船舶を抽出する手法が提 案されている (3) (4) (5) (6)。これらの手法は船上で撮 影した画像から効果的に船舶を抽出することが可能 であったが、処理のための演算負荷が重く結果がリ

\footnotetext{
* 学生会員 東京海洋大学 （广135-8533 東京都江東区越中島 2-1-6）

** 正会員 三菱電機株式会社（†100-8310 東京都千代田区丸の内 2-7-3） shimpo-masatoshi@mdis.co.jp

*** 正会員 東京海洋大学（干135-8533 東京都江東区越中島 2-1-6）
} 
アルタイムに得られないという久点があった。処理 に用いたコンピュータ装置によっては船舶の抽出処 理に数十秒掛かることもあった。そこで本論は既存 の手法では演算に時間が掛かりすぎて問題となって いる照合演算処理の替わりに、画像間の画素の移動 を高速に演算できる Lucas-Kanade 法を用いてリア ルタイムに抽出処理が可能な新しい船舶抽出手法を 提案する。東京湾で撮影した画像で既報と同様な処 理実験を行い、その効果を検証する。

以下に本論の構成を述べる。2 章では既存手法の 概要を述べて、問題点と高速化のための対策を述べ る。3 章ではリアルタイム化の具体的な手法を説明 する。4 章では実験に用いたシステムについて述べ て、実画像を処理した結果を示す。5 章で実験結果 を考察し、6 章でまとめる。

\section{2. 船舶抽出のリアルタイム化}

\section{1 既存手法}

既存手法のフローチャートを Fig.1に示す。

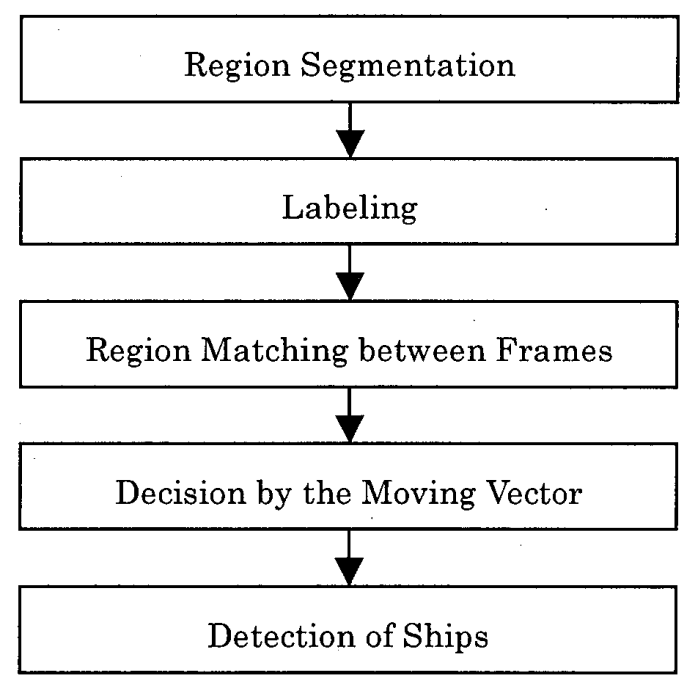

Fig.1 Flow chart of existing method.

以下に各処理の概要を述べる。

1. 明度情報を使って画像全体を領域に分割す る。

2. 個々の領域にラベルを付加する。

3. ラベルを付加した領域をテンプレートとし て任意時間後の画像上で照合処理を行う。

4. 照合の結果から各領域の移動べクトルを求 める。

5. 移動ベクトルの持つ性質から船舶の領域を 抽出する。

Fig.1 で示した処理のなかで最も時間を要するの
は照合処理である。照合処理とは分割した領域をテ ンプレートとして、任意時間後の画像の中で移動さ せながら、最も類似する場所を求める演算処理であ る。このときに用いる算出式を式(1)に示す。

$$
\mathrm{R}(\mathrm{u}, \mathrm{v})=\sum_{m=0}^{T X-1} \sum_{n=0}^{T Y-1}\left|I_{(u, v)}(m, n)-T(m, n)\right|
$$

式(1)は、テンプレート画像 $\mathrm{T}$ と被照合画像 I との 残差 $\mathrm{R}$ を求める算式である。ここで $I_{(u, v)}(m, n)$ は被 照合画像の明度を表し、 $T(m, n)$ はサイズが $(T X, T Y)$ のテンプレート画像の明度を表す。何れも画素単位 である。(u,v)は被照合画像 I 上における、テンプレ 一ト画像 $\mathrm{T}$ の左上座標を示している。 $\mathrm{R}$ が最も小さ くなるI の座標 $(u, v)$ 照合点として求めることが 出来る。この様な照合処理によって領域の正確な移 動場所を求めることが出来る。

処理時間を短縮する方法として次のような方法 がある。

1. 微小時間のフレーム間では領域の移動する 範囲は限られることから、演算する $(u, v) の$ 範囲を限定することが出来る。

2. 残差逐次検定法を用いて不要な演算を省略 し、高速化を図る手法が報告(7)されている。

しかし照合処理は分割した領域の全てについて、 個々の領域の予想移動範囲にわたって演算を実行し なければならず、て長な処理であることは否めない。 実験による処理時間の計測結果からもリアルタイム 化には不向きな手法といえる。この照合処理を改善 することが高速化にとって最も重要な課題である。

本論は膨大な処理時間を要する照合処理に替え て、高速に画素の移動べクトルを求め、且つ同等の 精度を得られる方式を用い、リアルタイムに船舶を 抽出出来る手法を提案する。

\section{2 提案手法の概説}

フレームレートが $100 \mathrm{~Hz}$ から $1000 \mathrm{~Hz}$ といった 高速なビジョンチップが試作されている(8)。このよ うなビジョンチップを搭載したカメラでは、撮影し たフレーム間の画像変化が小さいため各種の画像処 理手法を簡単に実現することが出来る(9)。しかし本 論では実用性を考慮しこの様な特別なチップを搭載 したカメラではなく、通常のビデオ信号のレート $(30 \mathrm{~Hz})$ で撮影されるカメラの画像を対象とする。

フレーム間の画素の移動を高速に算出する手法 として Lucas-Kanade 法が知られている(10)。この 
手法は物体が移動する際に、微小な時間間隔では画 素の輝度は変化しないという前提に基づいている。 手法の詳細は 3.3 節で述べるが、この手法を用いれ ば画素の動きを高速に求めることが出来る。これは 一般的にはオプティカルフローの抽出とも呼ばれて いる。

フレーム間での画素の動きが求まっても、これだ けでは必要な移動べクトルは求まらない。 Lucas-Kanade 法は微小時間間隔（概ね 0.03 秒 -0.04 秒）での画素の動きを対象としている。この ため分析に必要とされる時間間隔（概ね 0.3 秒一0.6 秒）での動きを求めるためには同手法で求めた画素 の動きを相当する時間分だけ連結する必要がある。 この連結処理の結果から移動べクトルの直進性等の 性質を求めることが出来る。

既存の手法では画像を領域に分割することによ つて船舶の領域を推定した。これに対して本提案手 法では同じ移動べクトルを持つ画素の集合を対象と する。画像上では船舶の周辺は輝度の変化による縁

(エッジ) として表れるので、この縁の動きを船舶 の動きとして捉えることが出来る。

海面や天空等の輝度の変化が一様な部分は処理 の対象外として不要な演算を省略することが出来る。 縁の動きを移動べクトルとして捉え、その移動の特 徵から船舶、波そして背景を分離して船舶のみを抽 出する。この分離手法については既報の方式(11)を踏 襲する。

\section{3. 提案手法}

\section{1 提案処理フロー}

\section{1 .1 フローチャート}

提案手法のフローチャートを Fig.2 に示す。

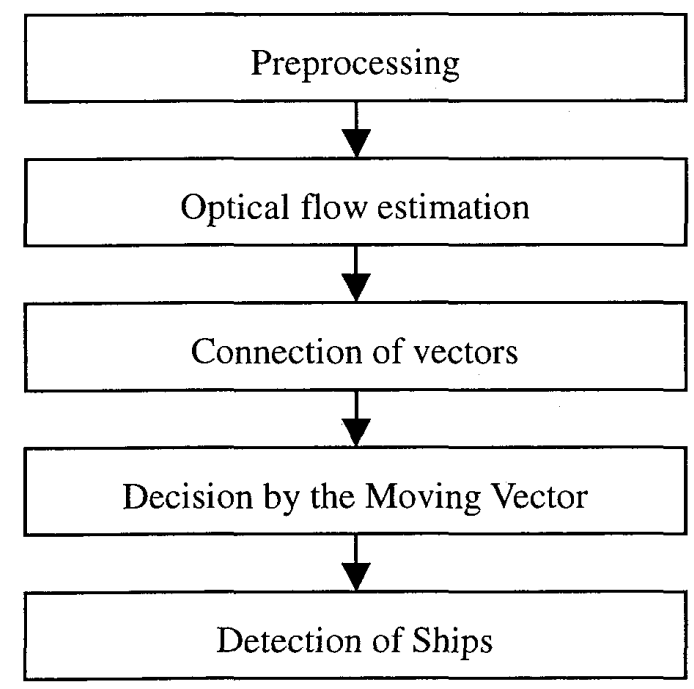

Fig.2 Flow chart of proposed method

\subsection{2 画像入力}

画像は時系列画像から等間隔に入力する。全画像 を対象にしてオプティカルフローを計算しても、動 きが非常に小さすぎるため特徴がつかめない。そこ で本論では先の報告を参考に 4 フレームの間隔を置 いて画像を入力する(5)。

時系列画像上から 4 フレームの間隔で画像を入力 し、各画像間のオプティカルフローを求める様子を Fig.3に示す。

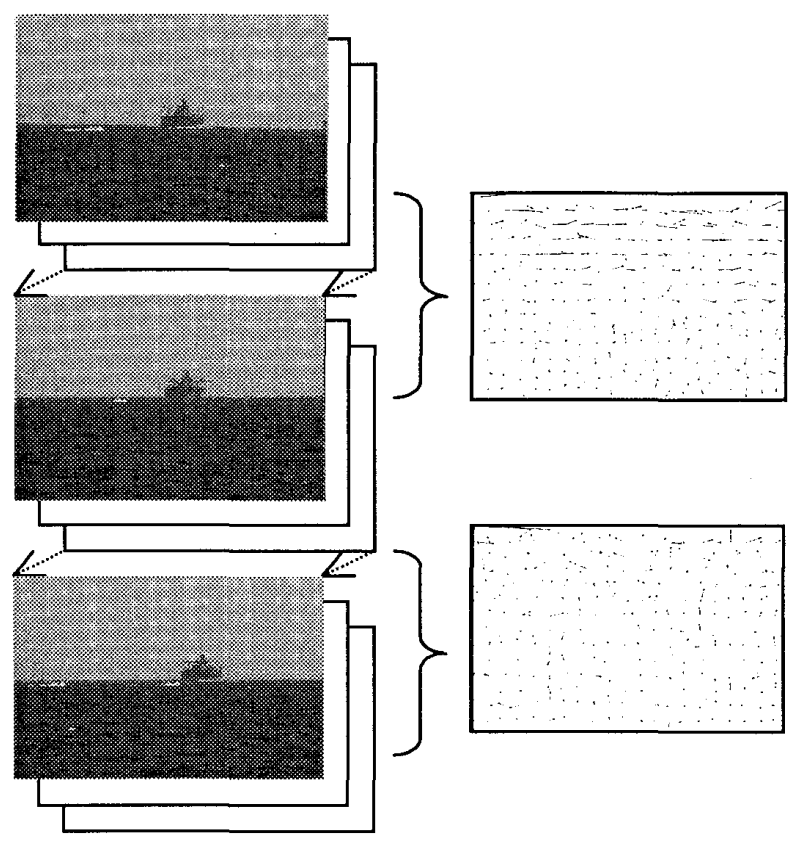

Input image Optical flow

Fig.3 Input of frames and optical flow estimation.

\subsection{3 オプティカルフローの抽出}

オプティカルフローとは画像中の各画素におけ る速度ベクトルの集合である。その計算法は様々で、 差分法、照合法、勾配法などがあり、対象物の性質 から適切に選択する必要がある。本論では勾配法の 一つである Lucas-Kanade 法を用いた。勾配法とは 動画像から時間的に隣接した 2 フレームを取り出し、 対象画素の空間的、時間的明るさ勾配をもとに速度 ベクトルを計算する方式である。2 つのフレームか らオプティカルフローを求める関係は Fig. 3 に示す 通りである。

\subsection{4 ベクトル判別による船舶の抽出}

Fig.3 に示すように 3 つのフレームからこれらの 間の 2 つのオプティカルフローを算出することがで きる。このようにして求めたオプティカルフローを 
連結して画素の移動べクトルを求める。その中から 直進性のあるべクトルを船舶の候補として抽出する。 Fig.4に移動べクトルを連結する様子を示す。
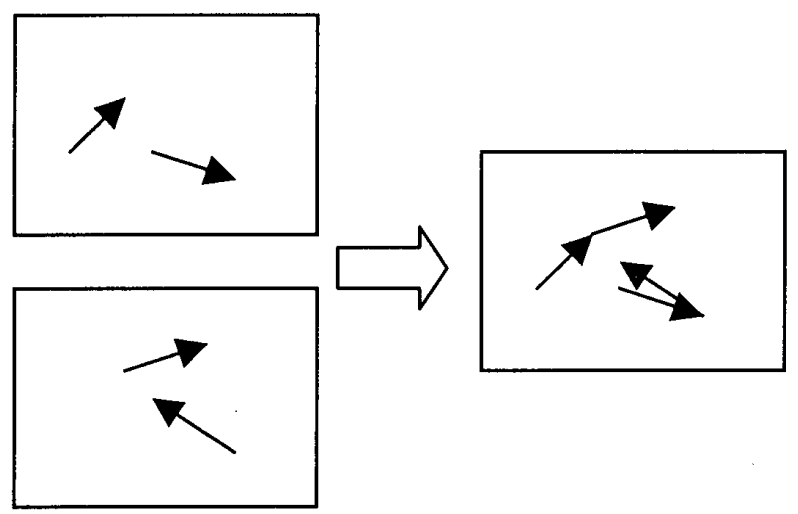

Fig.4 Connection of vectors from 2 frames.

\section{2 前処理}

\subsection{1 モノクロ化}

オプティカルフローは画像の明度勾配を手がか りとした速度べクトルの計算法であるので、撮影し た画像をモノクロ化する。

\section{2 .2 平滑化}

画像から明るさ勾配を精度よく計算したい場合 には、平滑化により雑音を抑える必要がある。本論 では平滑化の度合いを調節しやすいガウシアンフィ ルターを用いる。

\subsection{Lucas-Kanade 法}

本節ではオプティカルフローの算出に用いる Lucas-Kanade 法を説明する。

ある位置 $(x, y)$ 時間 $t$ の画素の明るさを $I(x, y, t)$ と表す。微小時間ずれた画素の明るさは $I(x+d x, y+d y, t+d t)$ と書ける。これをテイラー展開す ると式(2)のようになる。

$$
\begin{aligned}
& I(x+d x, y+d y, t+d t) \\
& =I(x, y, t)+\frac{\partial I}{\partial x} d x+\frac{\partial I}{\partial y} d y+\frac{\partial I}{\partial t} d t+\cdots
\end{aligned}
$$

式(2)の 2 次以降の項を無視すると式(3)となる。

$$
\begin{aligned}
& I(x+d x, y+d y, t+d t) \\
& =I(x, y, t)+\frac{\partial I}{\partial x} d x+\frac{\partial I}{\partial y} d y+\frac{\partial I}{\partial t} d t
\end{aligned}
$$

等明るさ仮定により、ある画素 $(x, y)$ の輝度 $I$ は $d t$ 後の移動先 $(x+d x, y+d y)$ でも同じであるとすると 式(4)が成り立つ

$$
I(x+d x, y+d y, t+d t)=I(x, y, t)
$$

よって式(3)は式(5)となる。

$$
\frac{\partial I}{\partial x} d x+\frac{\partial I}{\partial y} d y+\frac{\partial I}{\partial t} d t=0
$$

ここで $x, y$ 方向の速度べクトルを式(6)で定義する。

$$
\frac{d x}{d t}=u \quad \frac{d y}{d t}=v
$$

式(5)を $d t$ で割ると

$$
\frac{\partial I}{\partial x} u+\frac{\partial I}{\partial y} v+\frac{\partial I}{\partial t}=0
$$

この式(7)より導かれる速度べクトル $(u, v)$ を、一般 に勾配法によるオプティカルフローと呼ぶ。

式(7)だけでは速度べクトルを一つに定めること ができない。ここで様々な条件を付加することによ って解くことができる。Lucas-Kanade 法は、隣接 する画素は同じ速度べクトルをもつと仮定すること により、高速に解を導き出せる。

式(7)を式(8)で書き直し、隣接する画素がすべて同

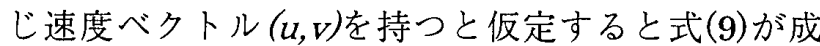
り立つ。

$$
\begin{aligned}
& \frac{\partial I}{\partial x}=I_{x} \quad \frac{\partial I}{\partial y}=I_{y} \quad \frac{\partial I}{\partial t}=I_{t} \\
& {\left[\begin{array}{cc}
I_{x 1} & I_{y 1} \\
I_{x 2} & I_{y 2} \\
\vdots & \vdots \\
I_{x n} & I_{y n}
\end{array}\right]\left[\begin{array}{l}
u \\
v
\end{array}\right]=\left[\begin{array}{c}
I_{t 1} \\
I_{t 2} \\
\vdots \\
I_{t n}
\end{array}\right]}
\end{aligned}
$$

式(9)を最小二乗法により解くと式(10)になる。

$$
\left[\begin{array}{l}
u \\
v
\end{array}\right]=\left[\begin{array}{cc}
\sum I_{x i}^{2} & \sum I_{x i} I_{y i} \\
\sum I_{x i} I_{y i} & \sum I_{y i}^{2}
\end{array}\right]^{-1}\left[\begin{array}{l}
-\sum I_{x i} I_{t i} \\
-\sum I_{y i} I_{t i}
\end{array}\right]
$$

この $(u, v)$ が求める速度べクトルである。

\section{4 ベクトル判別}

\subsection{1 ベクトルの直進性}

連結された 2 本のベクトルの直進性を判定するた

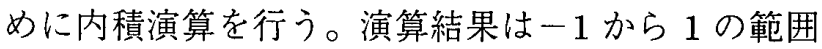
をとる。

\subsection{1 エッジ条件の付加}

画像中の急激な輝度変化がある場所では Lucas-Kanade 法の信頼度が低いことが知られて いるので計算からは除外する。輝度勾配を計算し、 勾配が急な場所は処理の対象としない。 


\section{4. 実験結果}

\section{1 実験システム構成}

\subsection{1 ハードウエア構成}

実験に使用した機器はビデオカメラ、IEEE1394 ケーブルおよび PCである。ハードゥエア構成の写 真を Fig.5 に示す。

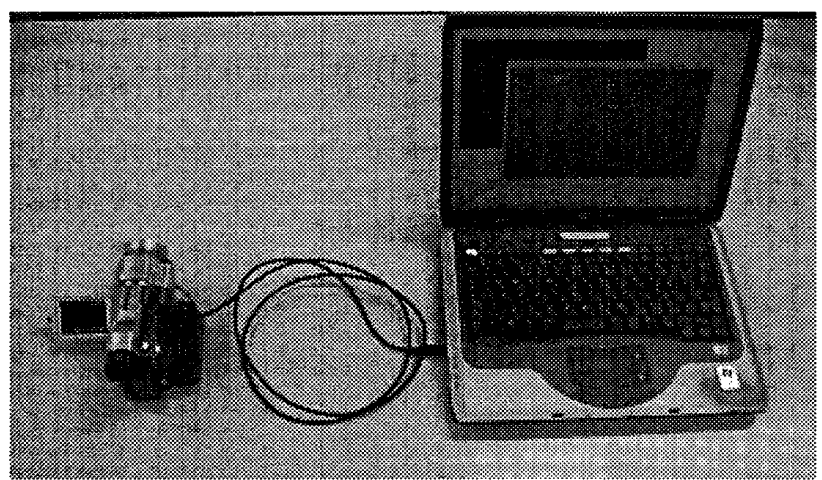

Fig.5 Hardware component.

\subsection{2 ソフトウエア構成}

プログラムはVisual C++を用いて構築した。動画 の入出力には Intel Open CVのライブラリーを使 用した。

\section{2 実験データ}

実験には東京湾を航行中にビデオカメラで撮影し た、9 日間で延べ 18 時間分の録画デー夕用いた。画 像の一例を Fig.6に示す。それぞれ撮影した画像の 1フレームを示している。撮影場所は a)浦賀水道航 路、b)館山沖、c)相模灘、d)金谷沖近辺である。

\section{3 処理画像}

本論の手法で処理した結果の画像を Fig7 に示す。 船舶として抽出された部分を白抜きで示している。

\section{4 処理時間}

画像を入力して結果を出力するまでの処理時間を 処理項目毎に Table.1に示す。

Table.1 Result of processing time.

(Second)

\begin{tabular}{|c|c|c|c|c|}
\hline Scene & Preprocess & LKM & $\begin{array}{c}\text { Decision by } \\
\text { moving vector }\end{array}$ & Total \\
\hline $\mathrm{a}$ & 0.01 & 0.09 & 0.52 & 0.62 \\
\hline $\mathrm{b}$ & 0.01 & 0.09 & 0.53 & 0.63 \\
\hline $\mathrm{c}$ & 0.01 & 0.09 & 0.53 & 0.63 \\
\hline $\mathrm{d}$ & 0.01 & 0.09 & 0.54 & 0.64 \\
\hline
\end{tabular}

各シーンで倍率や背景が異なるが画像処理に要
する時間はほぼ平均して 0.63 秒であった。処理の中 ではべクトル判定に最も時間を要している。

\section{5. 考察}

\subsection{Lucas-Kanade 法について}

本論は領域の照合処理という膨大な時間を要す る既存手法の替わりに、画素のオプティカルフロー から移動べクトルを求めるという手法を提案した。

この手法の中核となるのが Lucas-Kanade 法である。

Lucas-Kanade 法は短時間間隔のフレーム間で且 つ輝度の変化がある部分について高速にオプティカ ルフローを求めることが出来る。しかし、この条件 に当てはまらない場合は良好な結果が求められない。 そのため一旦求めたオプティカルフォローのベクト ルを連結して移動べクトルとする加工が必要となる。 実験ではこの様な処理を加えてもトータルで良好な 高速性能を発揮することが出来た。また抽出性能も 既存手法と同等であるため、今後見張り支援システ ムを構築する際に抽出手法の中核として期待するこ とが出来る。

\section{2 抽出性能}

4 章で示した実験の結果から以下の現象が判明し た。それぞれの現象が発生する理由と対策を述べる。

1. 船体の周辺部分が抽出される。

本論で用いた Lucas-Kanade 法はグラデーショ ンのある領域、すなわち輝度の変化がある領域のべ クトル場を高速に求める手法である。従って一様な 明るさの領域については移動べクトルを求めること が出来ない。この様な機能上の制限はあるが、船体 の周囲部分は船体と同様な動きをしているので船舶 として抽出することが出来る。

もし船体全体を画像上で確認する必要がある場 合は抽出した画素の周辺をさらに領域分割、結合の 手法等により船体を定義する必要がある。この処理 は抽出後の後処理となるので抽出毎に定義するのは リアルタイム化には不利である。船舶の存在を確認 する目的は本手法でリアルタイムに達成できるので、 船体の定義は必要に応じて後処理する方が望ましい。

2. 波が誤って抽出されることがある。

波が船舶と同様な直進運動をすると船舶として 誤抽出されてしまう。この現象は近距離で撮影され た波に発生しやすい。実験では色々な条件で海上を 撮影したため、直近の海面等、処理の必要がない部 分まで含むことがあった。本来この様な部分は撮影 の必要がないので、撮影範囲を限定することで相当 数の波の誤抽出を防ぐことが出来る。 


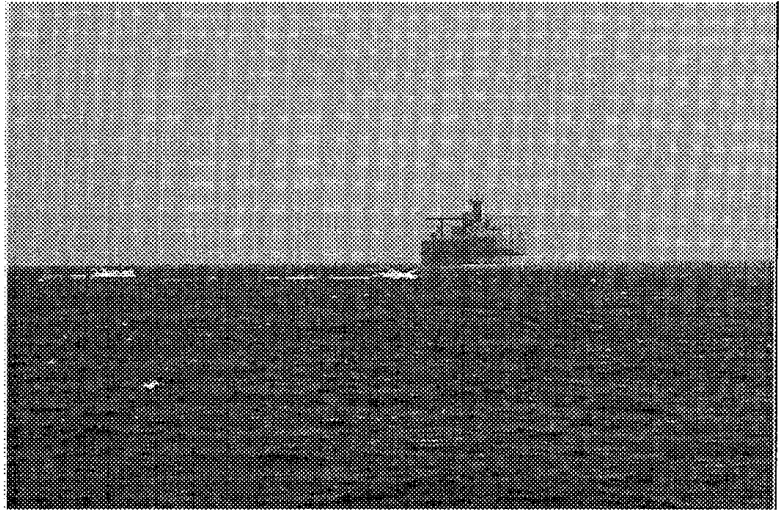

(a)

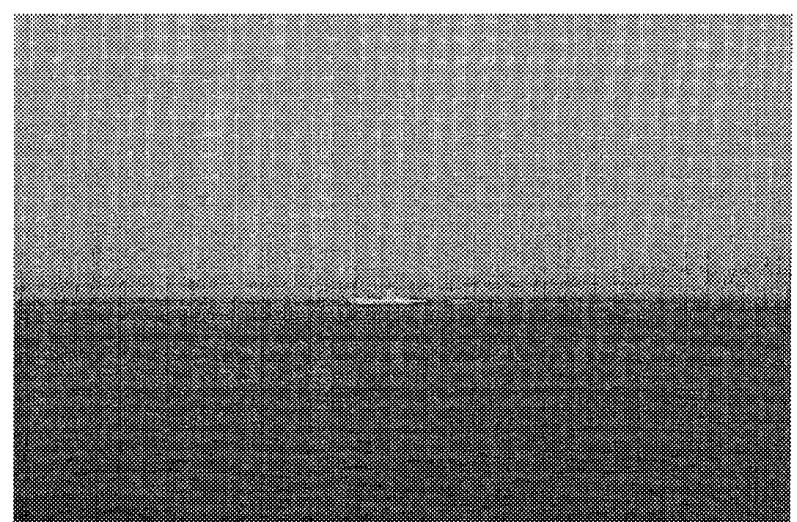

(b)

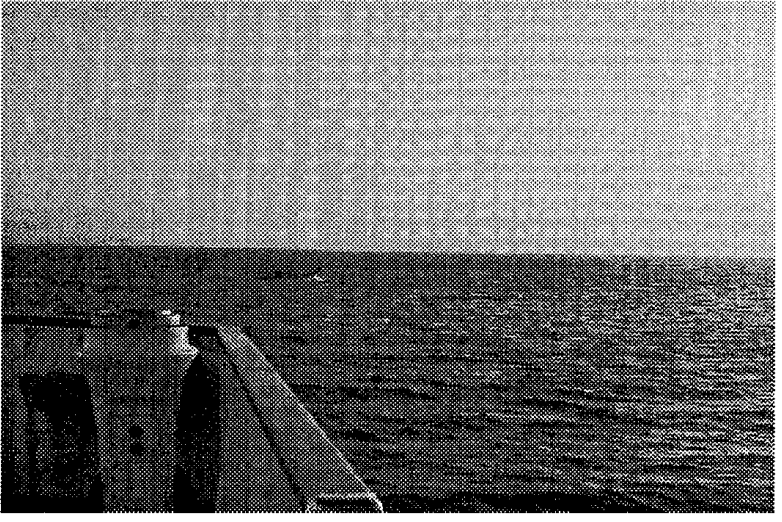

(c)

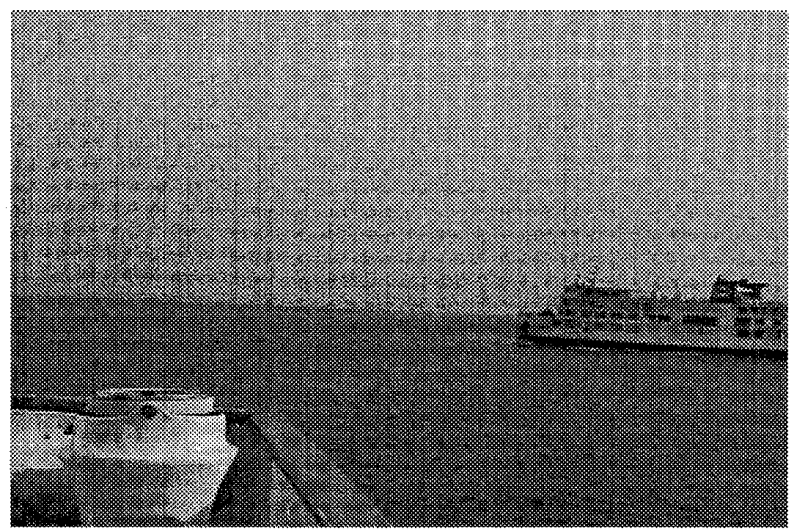

(d)

Fig.6 Experimental data.

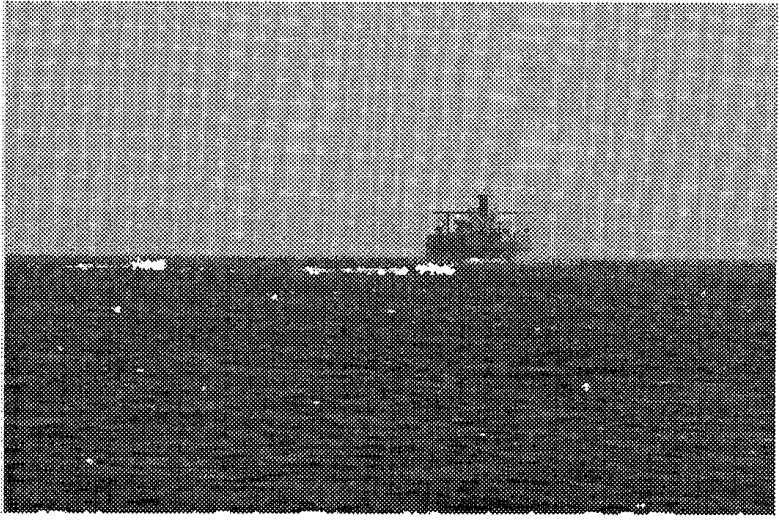

(a)

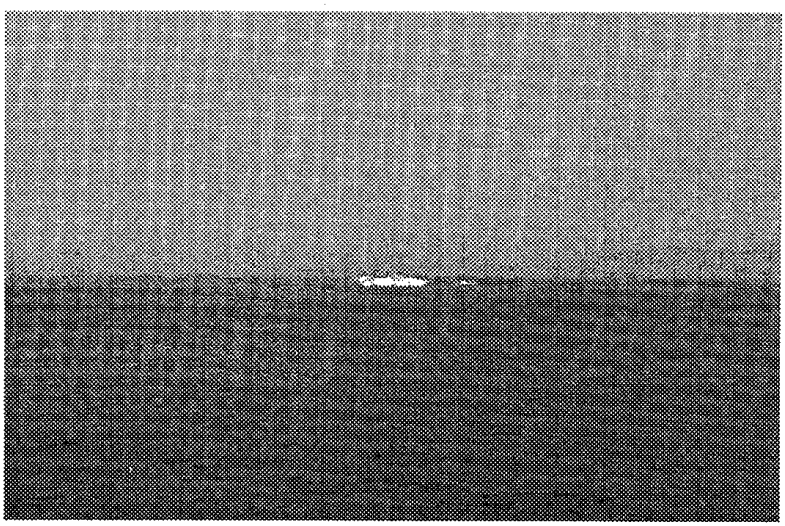

(b)

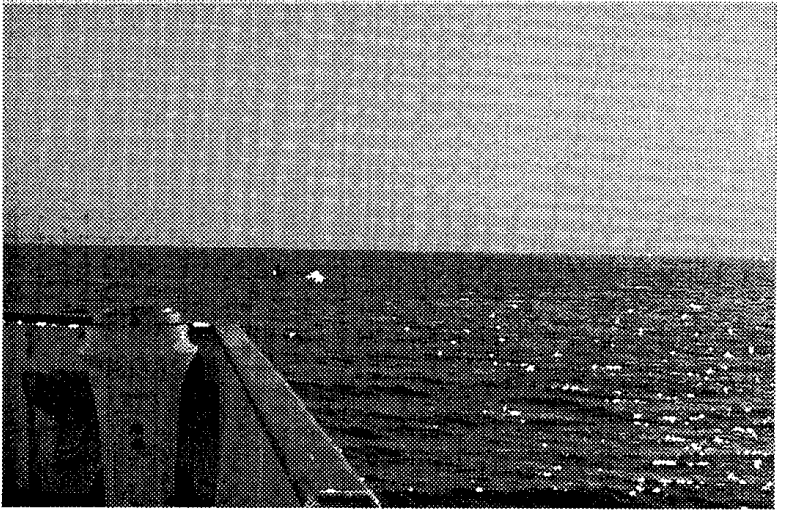

(c)

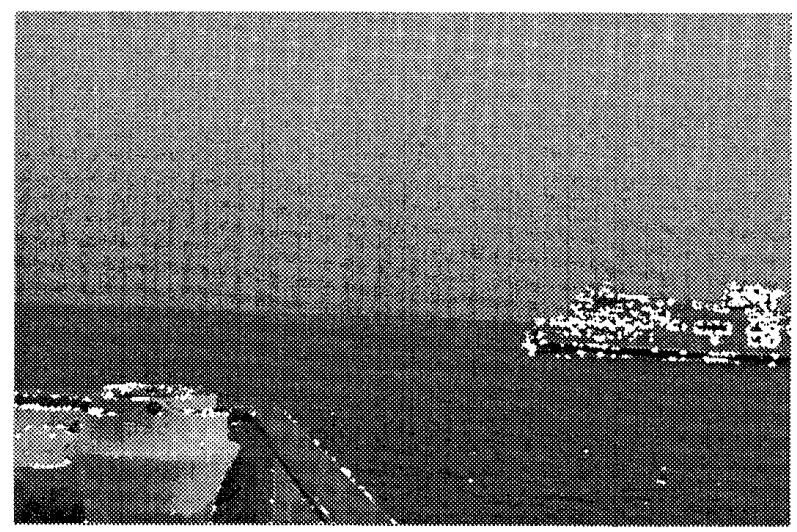

(d)

Fig.7 Result of proposed method. 
誤抽出してしまった波もある程度の時間（数秒以 内）の経過により形状が変形する(12)。従ってこの様 な部分は抽出処理を一定時間継続することで消失す るので波として除去することが出来る。

\section{3 処理時間性能}

第 4 章の処理時間の測定結果で示した通り、様々 な撮影シーンを処理した結果、処理時間は 0.62 秒か ら 0.64 秒の範囲にあった。処理に数十秒要した既報 のシステムに比べ大幅な高速化が実現できている。 この処理性能でほぼ実用上の性能を渵足していると いえるが、処理結果の画像を観察したとき表示が一 瞬止まる違和感を受けることがある。

完全なリアルタイム化を図るためにはビデオ信 号のフレーム間に相当する約 0.033 秒以内に全ての 処理を完了することが理想的である。この目標値は 抽出処理の結果を次の画像を待たせることなく表示 できる性能で、モニターを通して表示する構成であ れば画像にまったく違和感がないシステムが実現で きる。このためには CPU の高速化、高速演算処理 ボートの活用、画像入出力ポートの高速化等の対策 があげられる。

\section{4 実用性について}

本システムは波などの誤抽出を改善する必要は あるものの、船舶についてはほぼ確実に抽出できて いる。実際に船橋で見張り支援システムとして使用 する場合にはシステムが抽出した船舶の存在を航海 士の注意を喚起するために伝達する仕組みが新たに 必要となる。実用性に関してはこの様な航海士との インターフェイスが新たな課題である。

\section{6. むすび}

本論は Lucas-Kanade 法による高速なオプティ カルフロー算出手法を用いたリアルタイム船舶抽出 手法を提案した。実験により、本論の提案手法は既 報の手法に比較して高速に船舶を抽出出来ることを 示した。船舶の抽出機能や処理時間の性能には改善 の余地があり、更なる高機能化が期待出来る。これ らは実用化の際の課題とする。今後は様々な条件下 で撮影された画像を処理して抽出システムとしての 信頼性の向上に取り組む。

画像処理による航海の支援としては前述のよう に見張りの支援以外にレーダや AIS の監視支援が あげられる。本論で提案するような画像処理から得 た情報と既存の航海機器とを統合した「航海情報シ ステム」により、海難が減少することを熱望する次
第である。

\section{参考文献}

（1）海上保安庁：広報資料「平成 18 年における船舶 海難及び人身事故の発生と救助の状況」 http://www.kaiho.mlit.go.jp/info/tokei/index.

（2）新保雅俊：航海情報システム化のための時系列 画像処理に関する研究, 東京海洋大学学位論 文, 2004.9

（3）石村信道，林祐司，笠原包道，和気博嗣：航海 自然画像の領域分割に関する基礎研究，日本航 海学会論文集 88 号,pp.259-268, 1993.3

（4）今津隼馬 - 藤坂貴彦 - 福戸淳司 - 大竹祐一郎： 航行情報の統合と表示に関する研究、日本航海 学会論文集 109 号,pp133-140,2003.9

（5）新保雅俊，平澤雅人，大島正毅：時系列画像の 複雑背景下における抽出領域のフレーム間対応 を用いる航行船舶の抽出, 日本航海学会論文集 111 号,pp113-118,2003.9

（6）新保雅俊, 平澤雅人, 大島正毅：マルチセンサ 一により取得した航海環境時系列画像からの航 行船舶の抽出, 日本航海学会論文集 114 号,pp.65-72,2006.3

（7）高木幹雄，下田陽久監修：画像処理ハンドブッ ク

（8）小室孝, 石井抱, 石川正俊, 吉田淳, “高速対象 追跡ビジョンチップ, ”信学論 (D-II), vol.J84-D-II,No1,pp75-82,Jan. 2001.

（9）渡辺義浩, 小室孝, 鏡慎吾, 石川正俊, “ビジョ ンチップのためのマルチターゲットトラッキン グとその応用，"”信学論 (D-II), vol.J86-D-II,No10,pp1411-1419,Oct. 2003.

(10) Lucas B D and Kanade T, An iterative image registration technique with an application to stereo vision. Proceedings of Imaging understanding workshop, pp 121--130. 1981.

(11) Masatoshi SHIMPO, Yuefeng LU, Masaki OSHIMA," A Detection Method of Moving Ship from Navigational Image Sequence," The International Association of Institute of Navigation, $11^{\text {th }}$ IAIN World Congress, 2003.

（12）新保雅俊，大島正毅：フレーム間の照合性を手 掛りとする時系列画像からの航行船舶の抽出, 日本航海学会論文集 108 号,pp113-118,2003.9 


\section{質疑応答}

\section{奥田成幸 (海技大学校)：}

どの程度抽出できるのでしょうか。

\section{周立輝：}

画像上に映っている船舶で、形状が認識できる大 きさのものはほぼ抽出出来ます。遠方の船舶で画 面上で数ピクセルの小さなものは困難ですがそ の場合は望遠撮影に切り替えて拡大することで 抽出が可能となります。本提案手法はむしろ波の 誤抽出対策が問題となっております。

\section{奥田成幸 (海技大学校)：}

波は長時間観測すれば抽出されることはないと 考えてよいのでしょうか。

\section{周立輝：}

波は形状が変化するため通常数秒以内に消失し ます。従って抽出を継続して、取捨選択すれば船 舶だけを特定することが出来ます。

\section{福戸淳司 (海上技術安全研究所) :}

波の除去に苦労されておりますが、波を写さない ような撮影条件の検討をされておりましたらお 教えください。

\section{新保雅俊 :}

波の誤抽出で問題となるのは主に直近の海面部 分です。この付近の海面は波頭が明確に映り、一 定の方向に運動する波が多いという特徵があり ます。しかし極めて距離が近い範囲は処理する必 要がありませんので、撮影範囲を限定することは 波の除去対策として有効です。

また赤外線カメラを用いると白波の除去に有効 であることが分かっています(6)。

\section{福戸淳司 (海上技術安全研究所) :}

動きのない物標に対応するための工夫等があり ましたらお教えください。

\section{新保雅俊 :}

停泊中の船舶や浮標などが対象になると思われ ます。本論で扱う画像は動摇する船体から撮影し ていますので、画像全体に動きがあります。その ため動きの少ない領域を一様に背景として認識 しています。このとき、水平線を境に上側を陸地、 下側を海面上の物標とする判別が有効と考えら れます。 